\title{
Sheanut Oil
}

National Cancer Institute

\section{Source}

National Cancer Institute. Sheanut Oil. NCI Thesaurus. Code C71850.

An oil obtained from the seed of Butyrospermum parkii. Sheanut oil is used as an ing redient in skincare products. 